\title{
Conceptual Critic of Entrepreneurial Triadic Approach
}

\author{
Samuel Temitope Ogbara ${ }^{1}$, Salleh Din ${ }^{1}$, Hanif Suhairi Abu Barker ${ }^{2}$ \\ ${ }^{1}$ School of Business Innovation and Technopreneuship, Universiti Malaysia Perlis, Perlis, Malaysia \\ ${ }^{2}$ School of Human Development and Techocommunication, Universiti Malaysia Perlis, Perlis, Malaysia \\ Email address: \\ sam.ogbara@gmail.com (S. T. Ogbara)
}

\section{To cite this article:}

Samuel Temitope Ogbara, Salleh Din, Hanif Abu Barker. Conceptual Critic of Entrepreneurial Triadic Approach. American Journal of Operations Management and Information Systems. Vol. 3, No. 2, 2018, pp. 38-45. doi: 10.11648/j.ajomis.20180302.11

Received: February 26, 2018; Accepted: March 26, 2018; Published: April 28, 2018

\begin{abstract}
There is a general consensus among researchers that entrepreneurship has transmuted into a global phenomenon, thus demanding a global comprehensive understanding. Entrepreneurial concepts have metamorphosed over time and are inextricably connected with contemporary socio-economic development. The theoretical journey of entrepreneurship in relation to university-based entrepreneurial ecosystem development was traced and examined in this study using a sympathetic critical approach and the author plied a unique conceptual road map: Firstly, a broad spectrum approach was used to examine the conceptualization of the broad field of entrepreneurship as it evolves into entrepreneurial ecosystem. Secondly, criticism of entrepreneurship approach which aids in focusing and fine-tuning the substantive development of entrepreneurship is constructively significant for the development of 'smart' entrepreneurship. This study opens with the consideration and logical contemplation of the general entrepreneurship field, cardinal theories and current debates tailored to spur innovative entrepreneurial thought were dutifully delineated.
\end{abstract}

Keywords: Entrepreneurial, Entrepreneurial Ecosystem, Entrepreneurial Psychology and Substantive Theory

\section{Introduction}

A glut of seminal research has significantly validated the increasing cosmological significance of entrepreneurship in relation to global economic development [1-5]. Despite the fact that entrepreneurship approaches have had a cardinal impact in the developed world [6-7], access to capital and state-of-art technologies are not easily accessed, even market and product re-definition and re-modification assumes the transposition of timeworn technique, especially in developing countries like the study context, where access to stable power and capital are rare, entrepreneurial approach has some apparent and appalling weakness.

\subsection{Conceptualizing Entrepreneurial Approach}

Therefore, the evolution of entrepreneurship theories demonstrates the extensiveness and heterogeneity of the study at hand. Theories cardinally direct the intricate mesh mechanism of the growing concepts of entrepreneurship in relation to its subjacent outgrowth, entrepreneurial ecosystem. The subjacent concept occasions the formation of university-based entrepreneurial ecosystem, the subject of this study. The focal lens of these theories is multi-faceted yet uniquely tailored to the goals of this research.

In this study, the researcher would employ some approaches as shown in figure. 1, mainly economic, Psychological and Sociological approaches to buoy and solidify some of the arguments in the study, and the overall knowledge of extant approaches would assist the researcher to delve into the intricacies inherent in developing universitybased entrepreneurial ecosystem. Some of these cardinal approaches are briefly discussed below.

Figure 1 below shows the diagram and explanation of the dominant approaches in the development of entrepreneurial thought, and their linkage to another field.

\subsection{Issues in Conceptualizing Entrepreneurial Triadic Approach}

Dearth of research relating to pragmatically inclined entrepreneurship in the research location has occasioned limited understanding of the art of entrepreneurialism and purporting studies available are substantially deficient, mostly student-centered [75] while others are theoreticallyoriented without substantive pragmatic application [76-77]. 
Only a few studies amply considered entrepreneurial concepts in a panoramic context, and intrinsically, these few studies are devoid of the synergy between entrepreneurship and institutional application [77-78] and are unable to pragmatically garner substantive constructs that could be subservient for the building of an entrepreneurial theory, capable of mapping entrepreneurial readiness index. However, upon extensive search, the researcher acknowledges and solemnly states that there exist no substantive constructs for the development of entrepreneurial models in the context of the research. Most of the studies are theory-centered $[79,5,80]$ and the application of such theories for substantive development of an entrepreneurial essence, capable of mapping and predicting entrepreneurial realities in the research context is yet to be considered.

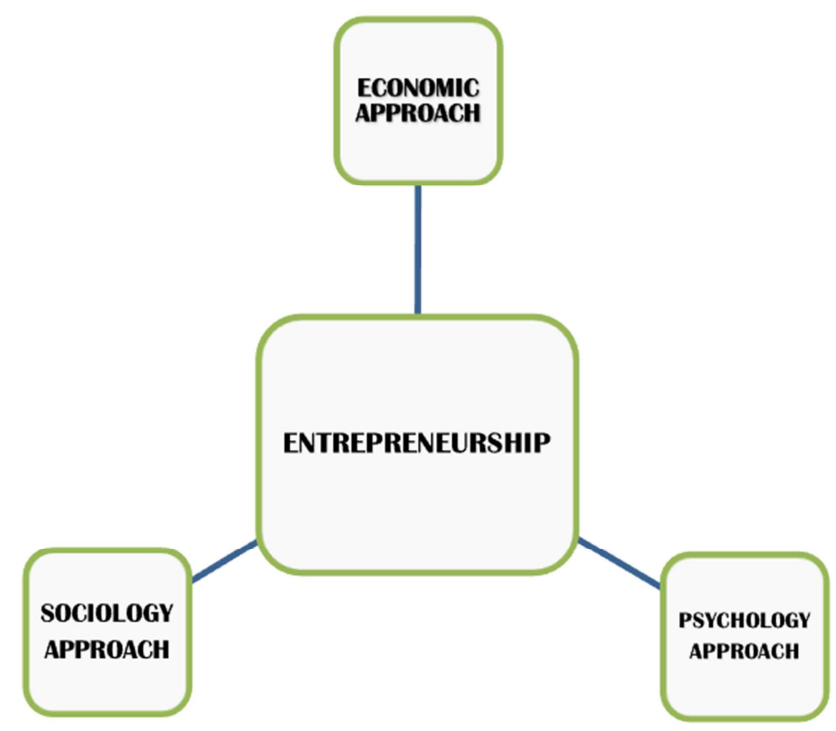

Figure 1. Shows the Major Triadic Approach to Entrepreneurial Conceptualization.

\section{Theorizing Entrepreneurial Evolution}

Unremitting ransacking of extant works concertedly evinces certain pressing gaps in global entrepreneurial research and a quantum shift in the paradigm of current entrepreneurial research due to the challenge of the dynamicity of globalization and volatility of today's market structures. It is interesting to state that these global issues are cardinally receiving global attention, from leading scholars and nascent researchers [74].

Issues in entrepreneurial research is significant to the present study due to the capacity and capability of entrepreneurship to resolve the present world's economic crisis, in fact, it has been empirically deduced that entrepreneurship has birth employment for over 250 million people in the world (GEM, 2015), this is statistically significant, considering the present population of the world. And, if increasing effort is given to solving the issues confronting entrepreneurial research, especially in the context of developing countries, almost half of the world's population would become gainfully employed, entrepreneurially.

\subsection{Theoretical Economic Approach}

Economic approach to entrepreneurial development has been hugely impacted by economic theories [8-10] and this approach concludes that entrepreneurship is the major determinant of economic advancement [11]. The hallmark of Schumpeterian entrepreneurial philosophy resonates this approach. Schumpeter [12] observes the entrepreneur as a combiner of new entrepreneurial reactants to form a new entrepreneurial product. Schumpeter's contribution to the economic approach of entrepreneurship has been regarded as the most towering work in the field of entrepreneurship and researchers have unanimously regarded him as the father of entrepreneurship [13]. Below are some appraisals of the economic approach in relation to entrepreneurial development:

i. Schumpeter's position, fundamentally corroborating economic approach could be summarily restated that an economic state would remain as it is unless an entrepreneurial force acts on it. Schumpeter refers to the entrepreneur as economic movers and shakers [14].

ii. Degree of domination is necessary to foster and further entrepreneurial innovative process in any economy [13].

iii. Economic approach forecast that the larger the firm, the more, the innovative capacity and competitiveness, and innovational markets are thresholds of better economic actions, as opposed to other classical entrepreneurial philosophy [15]

iv. Economic approach underscores Schumpeter's creation of markets by destruction of existing structures, and has been known to realize necessary disequilibrium for spurring commercialization activities, as opposed to Kirzner's philosophy which undermines the creative process of commercialization [8].

According to Schumpeter's economic approach, entrepreneurial roles are dynamic, innovative and transformational, thus changing the entire market reactants so as to bring about a new product [15-16]. Efforts at buttressing the economic approach necessitated the brief consideration of economic theory in the paragraph below. Economic theories are hinged on the fact that economic incentives cardinally drive entrepreneurial actions, and are circumstantially propitious [8]. Schumpeter's theory is the bedrock of economic theory and his contribution has further deepened economic theory. He posits that entrepreneurial actions are dynamic revolutionary and evolutionary activities that lead to innovation, and the entrepreneur must acknowledge and utilize all the emerging technologies for entrepreneurial development. Schumpeterian entrepreneur invents and re-defines market processes and operations, thus resulting in higher return in investment.

Concise Critic of the Economic Approach

The influence of the economic approach is cardinally 
limited to knowledge-based economies, and to locations where access to capital is not an issue. Despite the huge contribution of Schumpeter to the economic approach in relation to economic development, yet it has been the subject of several scholarly criticisms [9-10]. Schumpeter overstresses the behavior of the entrepreneur [17], and to have concluded that every entrepreneur must possess creative ability weakens this approach, in the context of contemporary verities. Most of the renowned entrepreneurial endeavors are carried out by entrepreneurs with limited skills and average mental capacity and some even have almost zero creative capability.

In addition, this approach assumes thorough innovative inventions and the landscape of today's business in developing nations favor incremental alterations [6, 18].

Schumpeter depicts entrepreneurial sphere of activities are large-scale, where there is massive availabilities of modern supports and techniques, whereas most of the business fonts are medium or small scale, improvising and managing the available meager supports and techniques. As regards entrepreneurial aptitude, the theory could not substantially explicate the reason why some economies have more entrepreneurial propensities, despite equal opportunities. The gender position of entrepreneur, as posited by Schumpeterian economic contribution to this approach, as majorly masculine activity, has found meager empirical support in contemporary economic context [7].

In a nutshell, the economic approach discussed uses the focal lens of the classical and neo-classical scholars, revolving around the equilibrium and disequilibrium position of the market and the entrepreneurial action and reaction to harnessing it for economic profit. The inherent weakness of the economic approach is the lack of consideration or an over-exaggeration of the entrepreneur's capability and ambience, and this necessitates the consideration of other traits of the entrepreneur in relation to entrepreneurial development [19-20].

\subsection{Theoretical Psychology Approach}

Psychological theories have significantly impacted the development of psychological approach to the development of entrepreneurialism. Psychological approach theorizes that certain personnel are more entrepreneurial than others due to some traits inherent in their biological constitutions, which can be honed and harnessed formally and informally, and has been asserted to further entrepreneurial development [21]. Despite equity in opportunities and privileges, some individuals would have more success in entrepreneurial endeavor than others [19]. Scholars agree that the possession of certain traits is cardinal to the development of entrepreneurship, while some have opined that the nascent stage of entrepreneurship demands the possession of certain entrepreneurial traits, though may become unnecessary in the face of growing demand for skills and other useful technicalities [22]. The description of this approach can be summarized below:

i. The works of [21] on the psychological constitution of the entrepreneur have found substantial support and are often rare in comparison to other populace [23].

ii. The trait school of thought became grounded and canonized in the late 1960 s, bothering mainly on the personality of the entrepreneur [24].

iii. There is no consensus about the mode of learning of these entrepreneurial characteristics $[25,26]$.

iv. Certain trait changes over the process of time and some characteristics are found to be permanent [27, 19].

v. Some traits have been identified to be conditionally spelt and time dependent while some traits are constant in the process of time [19].

vi. Ambitious and individuals with higher Need for achievement (NAch) are more entrepreneurial than others possessing lower Need for achievement [21], some few scholars have criticized this view [28].

vii. Extraversion and agreeableness, ability to freely and fully express oneself in relationship with others, have been attributed as key indicator to people becoming an entrepreneur [29]. These people could easily convey their entrepreneur interest and convince others in the face of seeming economic challenges to tow their entrepreneurial path. Scholars have conducted research to purport the validation of this view $[30,31]$.

viii.These entrepreneurs with high agreeableness are inherently trusty and customers and employee find it easier to repose confidence in them. Efforts at expanding the theoretical circumference of the psychological approach mandated the brief consideration of psychological theory in the paragraph below.

Proponents of Psychological theories such as McClelland and Winter [32] and McClelland [33] posited that there is positive relationship between the behavior of the entrepreneur and the opportunities and circumstances inherent in a given society [32]. Entrepreneurial activities have been directly linked to certain traits in their psychological constitution. This theory deduces that entrepreneurial behavior is molded during the formation of the individual. McClelland points out two traits that accelerate entrepreneurial development as novel and dependent on proper decision-making capacity. McClelland [21] contribution to the development of psychological theory could be summarized as follows:

i. Entrepreneurs possess a higher level of high achievement orientation.

ii. Traditional values have little impact on entrepreneurial achievement.

iii. The position of training is significant to the motivation of budding and soon-to-be entrepreneurs.

iv. Motivations are not genetically bound, though they are cardinal to the subsistence of business ventures.

v. Further psychological viewpoints conclude that entrepreneurs possess strong internal locus of control $[18,34]$. Locus of control expresses innate characteristics of the entrepreneur and the ability to 
solely utilize his inherent talents for entrepreneurial productivities, with little influence from external oddities. Research conducted by Frese and Gielnik [22] establish that proprietors of business are known to possess higher locus of control than ordinary members of the community. Here are some of the veritable assertions of this theory:

Generally, entrepreneurship is a concatenated concept with an array of interlocking phenomena, all converging to breakdown known barriers in business and seize every available opportunities for profitization [24]. Lack of unified understanding of the contextual significance of entrepreneurial roles in contemporary society has drastically hindered this approach [35] and inaptitude to discern market openings also hinders the tenor of trade [36]. Entrepreneurial traits have been argued to have some negative impact on employees, thus occasioning issues like over-management and infantilization of employees [37]. Internal locus of control (ILC) has been asserted to determine entrepreneurial propensity and the extent to which an individual fears external factors determines the overall entrepreneurial career and effectiveness of the entrepreneur [38]. Entrepreneurs who undermine fate and faithfully proceed in their entrepreneurial sphere with little anxiety over economic turbulence would record higher achievement and increasing entrepreneurial possibilities while individuals who possesses low internal locus of control would tactically suffer entrepreneurial defeat, and their possibility of starting a business is low [39]. This proposition has been buttressed by many empirical researches, and positive relationship has been recorded between high internal locus of control and entrepreneurial success, including higher rate of business start-ups [27, 40].

Self-efficacy mirrors the degree of confidence in one's initiative to meet certain demands regardless of inherent oddities. Bandura [41] and a host of scholarly researchers have empirically delved into the self-efficacy research and have concluded that individuals with high self-efficacy would be more entrepreneurial than other with low self-efficacy [42, 22].

\section{Concise Critique of the Psychological Approach}

Critiques of this approach abound, partly from a practiceoriented view of the entrepreneur and from the volatility of certain traits. Some of the grounds of objections to this approach are listed in the points below. Firstly, the famous entrepreneurial debate about the possession of entrepreneurial traits by nature or nurture is yet to be fully addressed and has left much doubt about the traits inherently responsible for successful entrepreneur [37, 43].

The contextual ambience of entrepreneurial endeavor has not yet been empirically measured to ascertain the conjectural propositions of the outcome of certain research [44]. The differences in entrepreneurial acumen and ability have account for some inconsistencies in researcher's findings [6]. Secondly, some of the studies conducted have negated the established fact, such that the possession of some of these renown entrepreneurial traits have sometimes (i) reduced entrepreneurial proclivity [45]; (ii) shows no positive relationship towards entrepreneurial outcome [46]; (iii) Only limited number of entrepreneurs have these entrepreneurial characteristics [47]; (iv) Scholars have argued that proper examination of certain traits could not readily differentiate someone who is entrepreneurial or not distinguish entrepreneurs from non-entrepreneurs [44]. Thirdly, there is a general demand for substantive frameworks that empirically mirrors personality character relative to their contextual ambience. Fourthly, critiques of psychological theories have bothered mainly on the connection of entrepreneurial actions with the entrepreneur's trait, often devoid of the ambience of the entrepreneur and this position lacks credence, [48] contemporary research asserts the verities and the significance of entrepreneurial ambience, as cardinal to entrepreneurial achievement [49], [50].

Research on the delineation of the aggregation of entrepreneur's physiognomies and not individual behaviour should be considered, though achieving this has been uneasy and such studies have been replete with mixed conclusions [37, 43, 51].

Therefore, as a result of the mixed conclusions in psychological traits research, some researchers have recommended that substantive model should be first generated with the hope that contextual issues of the participants in the present study would be fully considered, thus resulting in a more empirical approach to deciphering the psychological constitution of the entrepreneurial $[6,47]$.

\subsection{Theoretical Sociology Approach}

A sociological theory have impacted the formulation of the sociological approach and the substantive position of the entrepreneur's environment and associated factors relevant to the molding of the entrepreneur relative to entrepreneurial development [52, 53]. Atkinson et al. [53] advocates that scientific forecasting of human behavior should be in tandem to contextual surroundings. Furthermore, Social Learning Theory as formulated by Bandura proposes that personality differs on the basis of their contextual socialization [54]. The process of socialization in every environment could be formal and informal, often leading to certain experiences which make or mar entrepreneurialism [55].

According to Bandura's Social Learning Theory, behavioral characteristics are acquired through the following means (i) practice (degree of involvement in certain activities prior to entrepreneurial role); ii) Following exemplars or successful models; and, iii) peer influences [56].

The process of socialization has been significant to the attainment of several qualities which are accessory to entrepreneurial success [57]. Hence, the role of contextual factors inherent in entrepreneurial ambience has been cardinal in the shaping of entrepreneurial personalities, and the effects of these on the sociological approach to entrepreneurial development are listed as follows:

i. Parental role and circumstances (social attainments, career) have been found to induce entrepreneurial interest [43]. The probability of entrepreneurial parent 
birthing entrepreneurial responsive children is high [58].

ii. Prior entrepreneurial exposure significantly aids entry into entrepreneurial endeavor [59], [60].

iii. Scholars argue that social peculiarities, such as proper gender perception and social equipage and privileges are factors that foster interest in entrepreneurial career $[43,52,50]$.

iv. Marginal threshold favors entry into entrepreneurial career. Those at the margin of a social structure have higher entrepreneurial proclivity [61].

v. Ethnic disadvantages have been known to trigger entrepreneurial action. The case of foreigners in the UK and other nations are genuine examples [62].

vi. Circumstantial impediments have paved way for entrepreneurial abilities, circumstances such as retrenchment and apparent failures in certain career have been recognized to trigger genuine entrepreneurial interest $[63,64]$.

vii. Favorable entrepreneurial ambience and citadels are prime promoters of entrepreneurial actions $[65,66]$ and satisfactory entrepreneurial ambience often favors entrepreneurial actions.

viii.Institutional theory is the bedrock upon which the study of entrepreneurial action and ambience rests). Institutions are social environments that favor or disfavors entrepreneurial activities [67] Thus, the role of institutional theory is cardinal to the development of relevant entrepreneurial system and structures that would influence and stir genuine interest in entrepreneurial activities. Institution enables the soonto-be to be taught the art and skills relevant to pursue an entrepreneurial course, successfully, contextually and globally.

The main thrust of Sociological theories in relation to this approach is on social milieu, investigation of societal factors in relation to economic concerns is the boon and boundary of this theory [22, 44, 68] and they designate and partly determine the motivation and range of entrepreneurial action. Sociological theories as posited by Drucker [69] uphold the axiom that entrepreneurial action is catalyzed by societal values. These theories underscore the positive relation between social values and entrepreneurial ethos. The interdependence nature of societal ethos and entrepreneurial development occasioned the formulation of this theory.

The seminal works of Max Weber [70] and Hagen's theory of social change are the bedrock of sociological theory. Weber's research about the fostering effect of religion in entrepreneurial activities has been credited though it has met much criticism by some scholars who are averse to Protestantism. According to Weber, religiosity induces freedom and discipline to trade and maintain relevance and steady commercialization, with limited fear for uncertainty and risk, thus orchestrating entrepreneurial aptitude.

Moreover, another cardinal contribution of Weber [70] centers on the explorative and predictive effect of religiosity, both of which are designated to instill entrepreneurial ethos and principles, the effect of which could be seen in the society. Hagen [71] on the other hand, emphasized the position and productive place of innovation in the process of social change, all geared to bring about socio-economic advancement. The quirky nature of innovation, sometimes could hinder the cause of socio-cultural development, nevertheless, innovation, as represented by Hagen, is synonymous to social change. The thrust of sociological theory underscores entrepreneur's environment as cardinal to the overall process of socio-national advancement.

In a nutshell, the sociological approach proposes that entrepreneurial behavior is shaped by substantive context, which could be local or global.

Concise Critique of the Sociological Approach

(a) The critiques of Sociological approach devolve around the inability of the approach to clearly delineating the theory of entrepreneurial choice. Failure to explain entrepreneurial choice has been the weakness of this position. Regardless of the favorable ambience provided, certain individuals, and the society at large are far from becoming entrepreneurs [72].

(b) The examined conceptual scaffold are macrointensive, irrelevant in substantive context, the substantive profiles of many nations are not robust enough to engender serious entrepreneurial activities $[72,51]$.

\section{Conclusion and Recommendation}

Based on the afore-mentioned discuss of the theoretical proposition inherent in the historical purview of entrepreneurship, this section established that entrepreneurship is a comprehensive and complex phenomenon. Triadic approach was used to explicate the mesh mechanism of entrepreneurship. These include: the economic approach explains the role of the entrepreneur towards economic equilibrium and disequilibrium, the psychological approach underscores the traits relevant to favor or disfavor entrepreneurial pursuit, and the sociological approach directs the explication of the position of nature and nurture in the development of viable entrepreneurial system, contextually and globally.

The comprehensive study of entrepreneurial approach builds genuine entrepreneurial interest, which are harbingers of economic productivities, employment creation, and improvement of living standard. Finally, policy makers and stakeholders could trace the major milestones and contribution of their entrepreneurial theoretical journey after unraveling the mesh mechanism inherent in entrepreneurial activities on the basis of the triadic approach.

\section{References}

[1] Berglund, K., Johansson, B., \& Schwartz, B. (Eds.). (2012). Societal entrepreneurship: Positioning, penetrating, promoting. Edward Elgar Publishing. 
[2] Isenberg, D. (2014). What an entrepreneurship ecosystem actually is. Harvard Business Review, 5, 1-7.

[3] Adu, J. T., \& Cole, B. M. (2015, September). Entrepreneurship, Innovation and Economic Growth Index in an Emerging Economy: Nigeria as a Case Study. In European Conference on Innovation and Entrepreneurship (p. 9). Academic Conferences International Limited.

[4] Oziegbe, O. E., Oleabhiele, E. P., \& Adeyemo, A. D. (2015). Entrepreneurship education and sustainable development. Academic Research International, 6(2), 279.

[5] Ameh, A. A., \& Udu, A. A. (2016). Social networks and entrepreneurship orientation among students in nigerian universities: a study of social network size and risk disposition. Business and Management Research, 5(2), 1.

[6] Lombard, A. (2014). Entrepreneurship In Africa: Social Work Challenges For Human, Social And Economic Development1. Social Work/Maatskaplike Werk, 39(3).

[7] Addabbo, T., Modroño, P. R., \& Muñoz, L. G. (2015). Analytical Summary. Revista de Economía Mundial, 41, 103126.

[8] Filion, L. J. (1998). From entrepreneurship to entreprenology: the emergence of a new discipline. Journal of enterprising culture, 6(01), 1-23.

[9] Kaufmann, P. J., \& Dant, R. P. (1999). Franchising and the domain of entrepreneurship research. Journal of Business venturing, 14(1), 5-16.

[10] Redding, G., \& Witt, M. A. (2015). Advancing indigenous management theory: Executive rationale as an institutional logic. Management and Organization Review, 11(2), 179203.

[11] Boettke, P. J., \& Coyne, C. J. (2003). Entrepreneurship and development: Cause or consequence?. In Austrian economics and entrepreneurial studies (pp. 67-87). Emerald Group Publishing Limited.

[12] Schumpeter, J. A. (1934). Change and the Entrepreneur. Essays of JA Schumpeter.

[13] Gedeon, S. (2003). What is Entrepreneurship? Entrepreneurial practice review, 1(3), 18. Retrieved from: http://www.entryerson.com/epr/index.php/jep/article/viewFile/ $60 / 43$.

[14] Witt, M. A. (2008). Crossvergence 10 years on: Impact and further potential. Journal of International Business Studies, $39(1), 47-52$.

[15] Hock-Beng, C., 1990. Schumpeterian and Austrian Entrepreneurship: Unity within Duality, Journal of Business Venturing 5 (6), 341-347.

[16] Kirchhoff, B. A. (1994). Entrepreneurship and dynamic capitalism: The economics of business firm formation and growth. ABC-CLIO.

[17] Baumol, William J. "Formal entrepreneurship theory in economics: Existence and bounds." Journal of business venturing 8 , no. 3 (1993): 197-210.

[18] Loasby, B. J. (2015). Ronald Coase's theory of the firm and the scope of economics. Journal of Institutional Economics, $11(2), 245-264$.
[19] Shane, S. A. (2003). A general theory of entrepreneurship: The individual-opportunity nexus. Edward Elgar Publishing.

[20] Cope, J. (2005). Toward a dynamic learning perspective of entrepreneurship. Entrepreneurship theory and practice, 29(4), 373-397.

[21] McClelland, D. C. (1965). N achievement and entrepreneurship: A longitudinal study. Journal of personality and Social Psychology, 1(4), 389.

[22] Frese, M., \& Gielnik, M. M. (2014). The psychology of entrepreneurship. Annu. Rev. Organ. Psychol. Organ. Behav., 1 (1), 413-438.

[23] Schumpeter, J. (1958), Capitalism, Socialism and Democracy, Simon \& Schuster, New York, NY.

[24] Low, M. B., \& MacMillan, I. C. (1988). Entrepreneurship: Past research and future challenges. Journal of management, 14(2), 139-161

[25] Timmons, J. A., Muzyka, D. F., Stevenson, H. H., \& Bygrave, W. D. (1987). Opportunity recognition: The core of entrepreneurship. Frontiers of entrepreneurship research, $7(2), 109-123$.

[26] Gibb, A. (2007). Creating the entrepreneurial university: do we need a wholly different model of entrepreneurship. Handbook of research in entrepreneurship education, 1, 67103.

[27] Rauch, A., \& Frese, M. (2007). Let's put the person back into entrepreneurship research: A meta-analysis on the relationship between business owners' personality traits, business creation, and success. European Journal of work and organizational psychology, 16(4), 353-385.

[28] Littunen, H. (2000). Entrepreneurship and the characteristics of the entrepreneurial personality. International Journal of Entrepreneurial Behavior \& Research, 6(6), 295-310.

[29] Zhao, F. (2005). Exploring the synergy between entrepreneurship and innovation. International Journal of Entrepreneurial Behavior \& Research, 11(1), 25-41.

[30] Murnieks, C. Y., Mosakowski, E., \&Cardon, M. S. (2014). Pathways of passion identity centrality, passion, and behavior among entrepreneurs. Journal of Management, 40(6), 15831606.

[31] Elert, N., Andersson, F. W., \&Wennberg, K. (2015). The impact of entrepreneurship education in high school on longterm entrepreneurial performance. Journal of Economic Behavior \& Organization, 111, 209-223.

[32] McClelland, D. C., \& Winter, D. G. (1971). Motivating economic achievement: Accelerating economic development through psychological training.

[33] McClelland, D. C. (1987). Characteristics of successful entrepreneurs. The journal of creative behavior, 21(3), 219233.

[34] Åstebro, T., \& Chen, J. (2014). The entrepreneurial earnings puzzle: Mismeasurement or real?. Journal of Business Venturing, 29(1), 88-105.

[35] Germak, A. J., \& Robinson, J. A. (2014). Exploring the motivation of nascent social entrepreneurs. Journal of Social Entrepreneurship, 5(1), 5-21. 
[36] Huggins, R., \& Thompson, P. (2015). Entrepreneurship, innovation and regional growth: a network theory. Small Business Economics, 45(1), 103-128.

[37] Shane, S., Kolvereid, L., \& Westhead, P. (1991). An exploratory examination of the reasons leading to new firm formation across country and gender. Journal of business venturing, 6(6), 431-446.

[38] Artinger, S., Vulkan, N., \& Shem-Tov, Y. (2015). Entrepreneurs' negotiation behavior. Small Business Economics, 44(4), 737-757.

[39] Lüthje, C., \& Franke, N. (2003). The 'making' of an entrepreneur: testing a model of entrepreneurial intent among engineering students at MIT. $R \& d$ Management, 33(2), 135147.

[40] Espíritu-Olmos, R., \& Sastre-Castillo, M. A. (2015). Personality traits versus work values: Comparing psychological theories on entrepreneurial intention. Journal of Business Research, 68(7), 1595-1598.

[41] Bandura, A. (2001). Social cognitive theory: An agentic perspective. Annual review of psychology, 52(1), 1-26.

[42] Casson, M. (2003). Entrepreneurship, business culture and the theory of the firm. In Handbook of entrepreneurship research (pp. 223-246). Springer, Boston, MA.

[43] Stokes, D. (2000). Putting entrepreneurship into marketing: the processes of entrepreneurial marketing. Journal of research in marketing and entrepreneurship, 2(1), 1-16.

[44] Liñán, F., \& Fayolle, A. (2015). A systematic literature review on entrepreneurial intentions: citation, thematic analyses, and research agenda. International Entrepreneurship and Management Journal, 11(4), 907-933.

[45] Tang, M., Chen, X., Li, Q., \& Lu, Y. (2014). Does Chinese university entrepreneurship education fit students' needs? Journal of Entrepreneurship in Emerging Economies, 6(2), 163-178.

[46] Seilov, G. A. (2015). Does the adoption of customer and competitor orientations make small hospitality businesses more entrepreneurial? Evidence from Kazakhstan. International Journal of Contemporary Hospitality Management, 27(1), 71-86.

[47] Chen, M. H., Chang, Y. Y., \& Lo, Y. H. (2015). Creativity cognitive style, conflict, and career success for creative entrepreneurs. Journal of Business Research, 68(4), 906-910.

[48] Leutner, F., Ahmetoglu, G., Akhtar, R., \& ChamorroPremuzic, T. (2014). The relationship between the entrepreneurial personality and the Big Five personality traits. Personality and individual differences, 63, 58-63.

[49] Williams, C. C., Round, J., \& Rodgers, P. (2009). Evaluating the motives of informal entrepreneurs: some lessons from Ukraine.Journal of Developmental Entrepreneurship, 14(01), 59-71.

[50] Tehseen, Shehnaz, and T. Ramayah. "Entrepreneurial competencies and SMEs business success: The contingent role of external integration." Mediterranean Journal of Social Sciences 6, no. 1 (2015): 50.

[51] Stephan, U., Uhlaner, L. M., \& Stride, C. (2015). Institutions and social entrepreneurship: The role of institutional voids, institutional support, and institutional configurations. Journal of International Business Studies, 46(3), 308-331.

[52] Rae, D., \& Carswell, M. (2001). Towards a conceptual understanding of entrepreneurial learning. Journal of small business and enterprise development, 8(2), 150-158.

[53] Atkinson, R., Atkinson, K., Hilgard, E., (1983). Introduction to Psychology; The role of Psychology in Research.

[54] Bandura, A., 1982. Self-Efficacy Mechanism in Human Agency. American Psychologist 37 (2), 122.

[55] Sarasvathy, S., Kumar, K., York, J. G., \& Bhagavatula, S. (2014). An effectual approach to international entrepreneurship: overlaps, challenges, and provocative possibilities. Entrepreneurship Theory and Practice, 38(1), 71-93.

[56] Cumberland, D. M., Meek, W. R., \& Germain, R. (2015). Entrepreneurial self-efficacy and firm performance in challenging environments: Evidence from the franchise context. Journal of Developmental Entrepreneurship, 20(01), 1550004.

[57] Cacciotti, G., \& Hayton, J. C. (2015). Fear and entrepreneurship: A review and research agenda. International Journal of Management Reviews, 17(2), 165-190.

[58] Yu, L., Orazem, P. F., \& Jolly, R. W. (2014). Entrepreneurship over the business cycle. Economics Letters, 122(2), 105-110.

[59] Hisrich, R., Langan-Fox, J., \& Grant, S. (2007). Entrepreneurship research and practice: a call to action for psychology.

[60] Fayolle, A., \& Gailly, B. (2015). The impact of entrepreneurship education on entrepreneurial attitudes and intention: Hysteresis and persistence. Journal of Small Business Management, 53(1), 75-93.

[61] Anderson, A. R. (2000). Paradox in the periphery: an entrepreneurial reconstruction?. Entrepreneurship \& Regional Development, 12(2), 91-109.

[62] Casson, M. (1982). The entrepreneur: An economic theory. Rowman \& Littlefield.

[63] Burch, G. F., Batchelor, J. H., \& Humphrey, R. H. (2013). Emotional labor for entrepreneurs: A natural and necessary extension. Entrepreneurship Research Journal, 3(3), 331-366.

[64] Galindo, M. Á., \& Méndez, M. T. (2014). Entrepreneurship, economic growth, and innovation: Are feedback effects at work? Journal of Business Research, 67(5), 825-829.

[65] Rosenbusch, N., Rauch, A., \& Bausch, A. (2013). The mediating role of entrepreneurial orientation in the task environment-performance relationship: A meta-analysis. Journal of Management, 39(3), 633-659.

[66] Alvarez, S. A., \& Busenitz, L. W. (2001). The entrepreneurship of resource-based theory. Journal of management, 27(6), 755-775.

[67] Lawrence, T. B., Leca, B., \& Zilber, T. B. (2013). Institutional work: Current research, new directions and overlooked issues. Organization Studies, 34(8), 1023-1033.

[68] Su, J., Zhai, Q., \& Landström, H. (2015). Entrepreneurship research in China: internationalization or contextualization?. Entrepreneurship \& Regional Development, 27(1-2), 50-79. 
[69] Drucker, P. (2014). Innovation and entrepreneurship. Routledge.

[70] Weber, M. (1905). 2002. The Protestant Ethic and the "Spirit" of Capitalism and Other Writings.

[71] Hagen, E. E. (1962). On the theory of social change: How economic growth begins.

[72] Haugh, H. (2005). A research agenda for social entrepreneurship. Social enterprise journal, 1(1), 1-12.

[73] Fayolle, A., \& Liñán, F. (2014). The future of research on entrepreneurial intentions. Journal of Business Research, 67(5), 663-666

[74] Ojo, S., Nwankwo, S., \& Gbadamosi, A. (2013). Ethnic entrepreneurship: the myths of informal and illegal enterprises in the UK. Entrepreneurship \& Regional Development, 25(78), 587-611.

[75] Alias, A. J., Mokhtar, A. Z., \& Juri, A. H. (2005). StudentCentered Approach towards Technical, Learning, Social and Entrepreneurship Competencies at UniKL. In Proceedings of the 2005 Regional Conference on Engineering Education. Johor, Malaysia (pp. 163-167).
[76] Jamaluddin, A. \& Dickie, C. (2011).Decision-making related to business growth: Malay small business in Selangor. International Journal of Business and Management, 6(10), 284-296.

[77] Osibanjo, O. (2006). Concept of Entrepreneurship: A paper presented at the workshop on entrepreneurship and innovation for 200 level students in the University of Ibadan.

[78] Okojie, J. A. (2008, May). Policy framework and strategy for entrepreneurship development for Nigerian universities. In A Paper Presented at the National Sensitization Workshop On Entrepreneurship Development in Nigerian Universities Organized by National Universities Commission, Abuja (Vol. 21).

[79] Olorundare, A. S., \& Kayode, D. J. (2014). Entrepreneurship Education in Nigerian Universities: a tool for national transformation. Asia Pacific Journal of Educators and Education, 29, 155-175.

[80] Okumagba, P. O., \& Okinono, O. (2016). Human Capability and Entrepreneurial Development in the Niger Delta Region of Nigeria. 